\title{
LIEUTENANT-COLONEL CONSTANTIN APOSTOL, A GLORY OF THE ROMANIAN MILITARY SPORT
}

\author{
Gheorghe CALCAN \\ Petroleum-Gas University, Ploiești, Romania \\ calcangheorghe@yahoo.com
}

\begin{abstract}
Lieutenant Colonel Constantin Apostol (1903-1995) was born in a family of wealthy peasants from Săgeata commune, Buzău County. His studies were: primary school in his native town, high school in Buzău, followed by military studies, namely The Cavalry Officers School from Târgoviște, The Special Cavalry School and The Equestrian School in Sibiu. His military career evolved as follows: from a high school student (1924) to being a caporal, a sergeant and a plutonier (1925), a sub-lieutenant (1927), a lieutenant (1930), a captain (1938), a major (1943) and, at the end of his activity, a colonel lieutenant (1946). Constantin Apostol was considered one of the most prestigious representatives of the Romanian horse riding. He was an instructor and a teacher at the Equestrian School in Sibiu and at the Superior School of War. In the interwar period, Constantin Apostol represented Romania at numerous international equestrian contests, winning many awards, including the first prize in tournements such as those from Aachen (The Great Trophy), Brussels, Belgrade, Berlin, Duseldorf, London, Munich, Naples, Nice, Paris, Rome, Warsaw, Vienna, etc. For such results, his name was mentioned several times in the Day Order. Constantin Apostol remained active even after his retirement, when, while in reserve, he prepared the Romanian national team for the Olympics in Helsinki and Stockholm $(1952,1956)$ and was also the coach of Petrolul Ploiești Sports Club.
\end{abstract}

\section{Keywords: Constantin Apostol, interwar horse riding}

\section{Introduction}

In this paper we aim to present the outstanding activity and interwar achievements of Lieutenant Colonel Constantin Apostol in the field of horse riding. At the beginning of our analysis, we shall consider his family environment, we shall continue with his studies and further military evolution.

In order to materialize our aim, besides reading the already published information on Constantin Apostol, we conducted investigations both at the Romanian military archives in Pitești and in the native village of our hero.

\section{Personal background: family environment, studies, career \\ Constantin Apostol was born in Săgeata} commune, Buzău County, on April 20, 1903, as a son of the farmers Constantin Gh. Apostol and Dumitra (born, Lungu) [1]. The Apostol family, in which Constantin C. Apostol was born, was one of the wealthiest families in Săgeata. The name of Gheorghe Apostol, the father of Lieutenant-colonel Constantin Apostol, was mentioned in Socec Yearbook of Great Romania as the owner of a pub [2], while one of the uncles of C. Apostol was a lieutenant colonel in the army. Constantin C. Apostol had three siblings and a sister, all four working as 
primary school teachers.

After attending primary studies in his native commune, he attended eight classes at " $\mathrm{B}$. P. Hasdeu" Theoretical Lyceum, from Buzău, which he completed in 1924. He was a member of the high school's oina team and a player at "Vârtejul” Buzău football team [3]. Constantin Apostol continued his intellectual and professional training through military studies, namely: The Cavalry Officers School from Târgoviște (2 years, graduated in 1926), The Special Cavalry School from Sibiu (1 year, graduated in 1929) and the Equestrian School in Sibiu (1 year, graduated in 1930). He also learned French and German [1].

Constantin C. Apostol was a good student. He completed "King Ferdinand I" Military School from Târgovişte, with a general grade of 8.02, "ranking 4th out of 44 students"[1]. His record sheet at the end of the second year recorded the following appreciations: the squadron commander, Captain Chiricuță considered him healthy and resilient, with a beautiful military education. He proved military skills, work power, conscientiousness, right judgement and rode really well. Furthermore, Apostol had "beautiful qualities of a instructor", and if he were to continue his journey, "he would become a very good cavalry officer". The Commander of the Division, Major Ionescu perceived him as "a very good element from all points of view". In the commander's opinion, Apostol showed intellectual and moral qualities, had a good physical condition, being a very good sportsman as well. He was very serious and conscientious, with real instructor qualities, which made his commander state: "I foresee a very beautiful career." The Colonel who was the commander of the Cavalry School strenghtened all the appreciations made by his subordinates [1].

Constantin C. Apostol was also a good student while at the Special Cavalry School, whose courses he attended in 1929. He completed the courses with the average grade of 7.16, ranking sixth out of 41 graduates [1].

In 1930 Constantin C. Apostol completed the Equestrian Schools, his final qualification being "very good". Lieutenant-colonel Şendrea noticed his love for horseback riding and the fact that he could work with difficult horses. Apostol's skills were obviuous: "he jumps properly feeling the movement of the horse and with great enthusiasm," and "if he continues to work with the same love, he will have good results" [1]. The Commander of the Special Cavalry School, Colonel Alexandrescu, considered Apostol, in his second year of school and training, as being equally healthy and resilient, disciplined and conscientious, with good riding skills, as in the first year and “a very good officer". The general commanding the Cavalry School agreed with the appreciations of his subordinates about Constantin C. Apostol [1].

His military career started on October 1, 1924, at Târgoviște Cavalry School, as a volunteer (1st year student). His evolution was the following: a corporal (February 1, 1925), a sergeant (July 1, 1925), a plutonier (July 1, 1925), a sub-lieutenant (July 1, 1927), a lieutenant (April 1, 1930), a captain (January 24, 1938), a major (September 6, 1943) and a lieutenantcolonel on February 15, 1946 [1].

Throughout his career, Constantin Apostol started as a student of the Cavalry School of Târgovişte (October 1, 1924 - July 1926) and later worked as: a platoon commander of the Roșiori Regiment of Cernăuți (July 1926 - September 1930), a horseback riding instructor at Sibiu Special Cavalry School (September 1930 - January 1938), a squadron Commander of 6th Călărași Regiment, Brașov (January - October 1938), a riding instructor at the Special War School in Bucharest (October 1938 August 1943), as a division commander of Group 5 Research (August 1943 - July 1945), a commandant of CT. Buzău garrison (July 1945 - January 1948) and as the coach of the army's horseriding team (1 October 1953 - 1 March 1954) [1]. 


\section{On the heights of sport and military glory}

After his first military stage in Cernăuţi, in 1930, Constantin C. Apostol was transferred to Sibiu. At his departure, the commander of the 11th Roșiori Regiment, noted in the officer's record sheet: "He behaved very well under all circumstances, and I found him to be a very promising officer. The Regiment regrets the departure of this elite officer" [1]. In Sibiu, Constantin C. Apostol immediately became "an instructor to the students studying to become cavalry officers" and was remarked from the start due to his achievements in sports competitions. In his 1931 score sheet, it was noted that: "he is very good at all horse races in the country, winning several important prizes and a cup in the hardest race in Sibiu” [1].

Every year, the appraisals of his superiors were laudatory, highlighting his passion for horses ("He owns the most numerous and beautiful horses, all of pure blood"), his sport related dexterity ("a Horseman with a brilliant future”), education, general culture, behaviour towards both his superiors and inferiors ("exemplary conduct"). He was considered a "very good and promising officer" [1]. Colonel Pleniceanu, the commander of the Cavalry Application School in Sibiu, noted in the qualificative sheet for the year 1934 that lieutenant Constantin C. Apostol obtained "the same beautiful results in training, as well as in his military career and horseriding activity”. He continued to "get the most beautiful successes" at the national horse races and clearly distinguised himself among the comrades of his promotion, which made him a worthy candidate to be advanced in the military rank [1].

Constantin C. Apostol became a member of the national horseriding squad (together with Petre Chivulescu, Zehei and Tudoran), specialization Obstacles. In 1934, he won the "Mussolini" medal with horse "Joy" in Italy [3]. He also had remarkable results in 1935, for whom his name was mentioned by the General Inspectorate of the Cavalry in the Day Order [1].

The assessment sheet of 1936, recorded at the Cavalry Application School in Sibiu, was written by Colonel Grigore Vulturescu, who considered Lieutenant Constantin C. Apostol to have "exceptionally beautiful" physical skills, an admirable ability to climb the horse, being a "first-hand international horseman (our highlight Gh.C.) as his horseriding activity of this year has reached a very beautiful peak worthy to be admired and remarked." His selection in the national team "was one of the happiest, and Apostol proved that he really deserves the world wide reputation he has gained in this field".

Colonel Vulturescu insisted that Constantin C. Apostol participated in the international contests in Warsaw, Dusseldorf, Munich, Aachen and Vienna "where he reached great glory". The arguments were obvious and unbeatable: "In total, he won 30 awards and 7 mentions, of which - two first prizes and three cups". Moreover, "within the competition in Vienna he broke both the Austrian and Romanian record at heigh jump, reaching $2.10 \mathrm{~m}$, which he jumped with his horse over seven obstacles (our highlight)".

The appreciation of the commander surpassed the local level and reached a national and even international level, when considering: "All the successes of this officer in the field of horseriding contributed to a higher prestige of the Romanian army abroad and to a beautiful propaganda in favour of Romania”. Such appraisals were totally honest and unusual for the strict military style. Through all that Constantin C. Apostol did, he was considered to "have deserved all our gratitude”. He proved very good military skills, had a good professional culture that he would constantly strengthen, he was "an admirable, skilled and zealous person”.

The conclusions of colonel Vulturescu represented a beautiful eulogy: "To conclude, lieutenant Apostol Constantin is 
an element of great importance to our army and the field of horse riding, because due to him these can be known abroad, as domains with capable and brave officers that proved to be also very skilled horsemen. Therefore, for his great merit of having brilliantly affirmed in the country and abroad as an excellent horseman, thus bringing real services to the country, I propose [Apostol] to be promoted "at choice" to the rank of captain (our highlight)" [1].

The commander of the Cavalry School, general Constantin Atanasescu acknowledged the appreciation of colonel Vulturescu noting that lieutenant Constantin C. Apostol was "a distinguished rider and a good cavalry officer”, courageous, hard-working, modest, making "with the greatest conscientiousness all the assignments entrusted to him" [1].

The appreciations and remarkable results of Constantin C. Apostol continued. In 1937, his superiour proudly stated: "I am pleased to note that this year, Lt. Apostol has retained the same precious world renown as an international rider, participating in countless international horseriding competitions in which he took part throughout the year, and in which he gathered only laurels of victories for the army and the country". As a reward and recognition of these achievements, the name of Constantin C. Apostol was registered once again in the Day Order.

Day Order No. 114 of September 27, 1937, mentioned that Lieutenant Constantin C. Apostol, a riding instructor, together with two colleagues, participated in the contests of Paris, Brussels, Warsaw, London, Duseldorf, Insterburg, Berlin, Munich and Aachen. Constantin C. Apostol won 39 awards, the most numerous ones, of which one first prize. He won these awards as follows: in Paris - 2 awards, in Brussels - 7 awards, in Warsaw - 12 awards, with one first position, in Duseldorf - 1 award, in Berlin - 8, in Munich - 1 and in Aachen - 8 awards.
General Constantin Atanasescu, the commander of the Cavalry Schools, continued the laudative words of Colonel Vulturescu, noting that: "By their beautiful successes obtained in very difficult tests, disputed by perfect horsemen representing all nations, and riding highest class horses, these three officers have proven exceptional qualities of admirable riders, excellent skills and long-lasting work that greatly increased their experience and brought them a world-wide renown.

Their international activity from this year and the previous ones is real reason for the nation, the army and especially for our cavalry to be proud.

The Cavalry School of Education, the cradle of their daily workout, is honoured to have such valuable members.

Therefore, the commander and the officers of this institution woukd like to express their gratitude and admiration.

Those in charge will conform" [1].

In 1937, Constantin Apostol became a member of the prestigious "International Royal Horse" London Club [3]. In the following year, further outstanding results were recorded, Constantin C. Apostol taking part in "the international fair competitions of Nice, Rome and Warsaw, where he won again the laurels of victory, as in the past" [1].

Remarkable sport results and well-deserved appraisals continued. Priour to the announcement of World War II, in September 1939, in his qualifying sheet, there was written: "Pleasant physical appearance, very healthy and resilient. Excelent rider, who honours his field, took part in the horse races from Bucharest and Braşov, where he won various awards" [1].

Furthermore, Constantin C. Apostol participated in the military operations of the Second World War in both the East and West campaigns, being remarked and decorated for his military actions on both fields.

The establishment of the communist regime in August 1944 created the premises of the 
unnatural situation that gradually led to the psychic and physical humiliation and degradation of lieutenant-colonel Constantin Apostol.

After World War II, even if he trained the national team for the Olympics in Helsinki and Stockholm (1952, 1956) and was the coach of Petrolul Ploiești Sports Club, was sent to jail by the communist regime for the simple reason that he was part of the old national Romanian elite.

A late sign of rehabilitation for the humiliation that Constantin C. Apostol had to endure during the communist regime was the decision of the authorities from his native village to give his name to one of the main streets in Săgeata, in 2010 [4].

Lieutenant-colonel Constantin C. Apostol is still considered to be the most prestigious representative of the Romanian horse riding, along with Felix Tुopescu [5].

\section{Conclusions}

Constantin C. Apostol was, undoubtedly, one of the most prominent national military athletes, who proved a great passion for horses throughout his lifetime. During his military studies, he was permanently remarked for his good results and therefore, later on, he was chosen to be a member of the national horse riding team, participating in numerous international competitions. Apostol won many awards, and for these results, his name was repeatedly recorded in the Day Order, with extremely gratifying words.

Constantin C. Apostol was sent to the frontline of World War II military operations, where he proved heroism on both the Eastern and the Western fronts.

It is regrettable and reprehensible the fact that, after such a brilliant sports and military career, the communist regime humiliated him after 1944.

Constantin C. Apostol died in 1995. At the County Museum of Buzău, one can find a series of photographs, plaques, as well as the medals that this prominent sportsman won throughout his career.

\section{References}

[1] The Center for Studies and Preservation of the Historical Military Archives, Piteşti, Military Commissariat Collection, Buzău, Dos. Lt Colonel, Art. 6, f. 1-80.

[2] Socec Yearbook of Great Romania, Săgeata Village, Buzău, p. 134, On-line, http://lcweb2.loc.gov/cgi-

bin/ampage?collId=gdc3\&fileName=scd0001_20030122001ropage.db\&recNum=141, accessed on February, 4, 2018.

[3] Valeriu Nicolescu, Gheorghe Petcu, Buzău - Râmnicu Sărat, The Now and Then People, vol. I, Buzău, Appha MDN Publishing House, 1999, pp. 161-162.

[4] Gheorghe Calcan, Street Names in Săgeata, județul Buzău, Proceedings of the Second International Conference on Onomastics "Name and Naming" Onomastics in Contemporary Public Space, Baia Mare, May 9-11, 2013, Edited by Oliviu Felecan, Mega Publishing House, Argonaut Publishing House, Cluj-Napoca, 2013, pp. 254 - 262.

[5] Victor Andreica, Florentin - Stelian Albu, Looking for a New Chance, Săgeata, Buzău, Editgraph Publishing House, 2010, pp. 305-306. 